\title{
Evaluation of animal and veterinary science teaching at the University of Nairobi
}

\author{
U. B. LindSTRöм ${ }^{1}$ ) \\ Institute of Animal Breeding, Agricultural Research Centre Box 1801301 \\ Vantaa 30, Finland
}

\begin{abstract}
Sixty-two students, graduating in 1975 from the Faculty of Veterinary Medicine, University of Nairobi, Kenya, were sent a questionnaire, which was returned by 41 . The graduates scored 4 aspects of the teaching in each subject on a scale from 1 $=$ very poor to $5=$ very good. The overall average for all years was $3.51 \pm .45$, indicating that the teaching was regarded as satisfactory, but not as particularly good. The variation between subjects was large, the poorest subject getting an average score of $2.78 \pm .78$ and the best a score of $3.94 \pm .68$, the coefficient of variation ranging from 14 to 28 . In many subjects the practical instruction was rated much lower than the theoretical one, and in one case the difference was as large as 1.61 points. The use and quality of teaching material was generally rated lower than theoretical instruction, as were examinations. These results, as well as the comments provided by the students indicate that there is considerable scope for improvement of the teaching in many subjects.
\end{abstract}

\section{Introduction}

In all developing countries there is a severe shortage of academically trained agronomists and veterinarians. Therefore in many of these countries, including Kenya, serious efforts have been made to set up adequate university teaching programs in Animal Production and Veterinary Medicine. However, due to the necessity of training as many students in as short a time as possible, there are, naturally, practical difficulties in providing the right kind of instruction. Moreover, most universities in the developing countries have to rely very heavily on foreign teachers, a practice which in some ways may have undesirable effects.

It is generally agreed that good teaching requires good feedback. In other words, sound teaching programs require a continuous evaluation of the various types of instruction given to the students. Evaluation of teaching, generally done by interviewing the students, is nowadays routinely carried out at many

1) The Author was in $1972-74$ on the staff of the Department of Animal Production, the University of Nairobi. 
universities in the developed countries, CAMpbell (1972); Thorndike \& HAgen (1969). In most developing countries, however, this practice is still rare, although the need for it certainly is as great or greater than elsewhere (LINDSTRöM 1975).

The purpose of this study is to discuss the quality of teaching in 197174 at the Faculty of Veterinary Medicine at the University of Nairobi, Kenya, on the basis of interviews with a number of graduates.

\section{Material and Methods}

The material was collected in the beginning of 1976 by use of the questionnaire in Appendix $I$, where the theoretical and practical instruction as well as the teaching material and examinations were evaluated on a scale from $\mathbf{1}=$ very poor to $\mathbf{5}=$ very good. The questionnaire was sent to the 62 students, who had graduated the previous year from the Faculty of Veterinary Medicine and whose addresses were known. The majority of these (c. $60 \%$ ) came from Kenya, the rest mainly from Tanzania and Uganda, and a few from Ghana and Malawi. The whole class numbered a total of 73 students, but it was felt that to avoid any bias in opinions those repeating their final year in 1975/76 should be excluded. The questionnaire was returned by 41 of the 62 students, i.e. by about $2 / 3$, which seems a fairly representative sample. Average scores, standard deviations, and coefficients of variation for the various subjects and for 4 aspects of the teaching (Appendix I) were computed. Differences between subjects were analysed by t-tests and simple correlations between scores were calculated.

\section{Results \& Discussion}

\section{Differences Between Subjects}

Table 1 gives the average scores as well as the standard deviations for the various subjects. The overall score is 3.5 indicating that on the whole the teaching has been regarded as satisfactory, but by no means as good. There is relatively little variation between the average scores for the different years. The first and the final years of study show the lowest coefficients of variation. Between the subjects (within and between the years) there is considerable variation. The coefficients of variation range between 14 and $28 \%$, indicating great dissatisfaction with some subjects. This is clearly apparent from the differences in average scores. In the first year Biochemistry gets significantly lower ratings than Anatomy and Physiology (t-tests given in Appendix II). Anatomy is also rated higher than Physiology. In the second year Microbiology gets significantly higher scores than the other subjects, whereas the differences between the latter are negligible. In the third year the poorest scores are given to Special Pathology, which is rated significantly lower than the other subjects. The differences between Medicine, Surgery and Reproduction are small. In the fourth year Public Health and Surgery are rated significantly higher than Medicine, Reproduction and Obstetrics. 
Table 1. Average scores and standard deviations for the four years of study (scale from 1 to 5 ).

\begin{tabular}{|c|c|c|}
\hline Subject & $\begin{array}{l}\text { Average } \\
\text { score } \pm \\
\text { standard } \\
\text { deviation }\end{array}$ & $\begin{array}{c}\text { Coefficient of } \\
\text { variation } \\
\%\end{array}$ \\
\hline \multicolumn{3}{|l|}{ 1st year: } \\
\hline 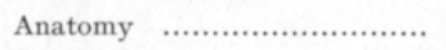 & $3.91 \pm .64$ & 16.4 \\
\hline 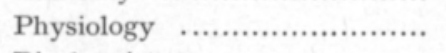 & $3.39 \pm .53$ & 15.6 \\
\hline 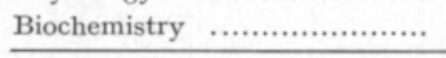 & $2.78 \pm .78$ & 28.1 \\
\hline & $3.35 \pm .43$ & 12.8 \\
\hline \multicolumn{3}{|l|}{ 2nd year: } \\
\hline Animal Production ................ & $3.37 \pm .82$ & 24.3 \\
\hline Pharmacology ..................... & $3.41 \pm .78$ & 22.9 \\
\hline Microbiology..$\ldots \ldots \ldots \ldots \ldots \ldots \ldots \ldots \ldots$ & $3.94 \pm .68$ & 17.3 \\
\hline 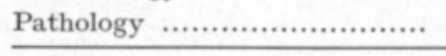 & $3.45 \pm .74$ & 21.4 \\
\hline & $3.53 \pm .55$ & 15.8 \\
\hline \multicolumn{3}{|l|}{ 3rd year: } \\
\hline Special Pathology .................. & $2.90 \pm .80$ & 26.8 \\
\hline Medicine........................... & $3.36 \pm .88$ & 26.2 \\
\hline 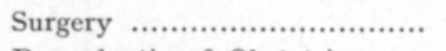 & $3.80 \pm .72$ & 18.9 \\
\hline Reproduction \& Obstetrics ....... & $3.52 \pm .84$ & 23.9 \\
\hline & $3.37 \pm .59$ & 17.5 \\
\hline \multicolumn{3}{|l|}{ 4th year: } \\
\hline 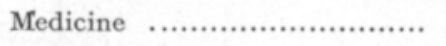 & $3.37 \pm .76$ & 22.5 \\
\hline Public Health $. . . \ldots \ldots \ldots \ldots \ldots \ldots . . . . . . .$. & $3.94 \pm .72$ & 18.3 \\
\hline 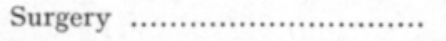 & $3.90 \pm .55$ & 14.1 \\
\hline Reproduction \& Obstetrics ...... & $3.52 \pm .82$ & 23.4 \\
\hline & $3.66 \pm .46$ & 12.6 \\
\hline 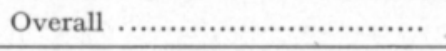 & $3.51 \pm .45$ & 12.8 \\
\hline
\end{tabular}

The low average scores, as well as the extremely large variation noted in some cases, indicate that many students have found serious faults in the teaching of these subjects. These opinions should not be dismissed lightly, but should encourage enquiries into ways of evaluating and improving the teaching.

\section{Different Aspects of Teaching}

In order to get a more detailed picture of the quality of teaching, each subject was viewed from four different aspects. (Appendix I). The average scores for these are presented in Fig. 1, and the overall association between the scores given by the same student to the 4 aspects is given in Table 2 . In general there is considerable agreement between the average scores for theoretical and practical instruction, although the latter are usually lower. However, there are some striking exceptions. In the second year, for example, Pharmacology gets an average score of 4.24 for the theoretical, but only 2.63 for the practical instruction. In the fourth year Surgery gets a score 
Fig. 1. Average scores for four different aspects of the teaching.

Anatomy

Physiology

Biochemistry

Anim. Prod.

Pharmacology

Microbiology

Pathology

Spec. Path.

Medicine

Surgery

Repr.\& Obst.

Medicine

Public Health

Surgery

Repr. \& Obst.

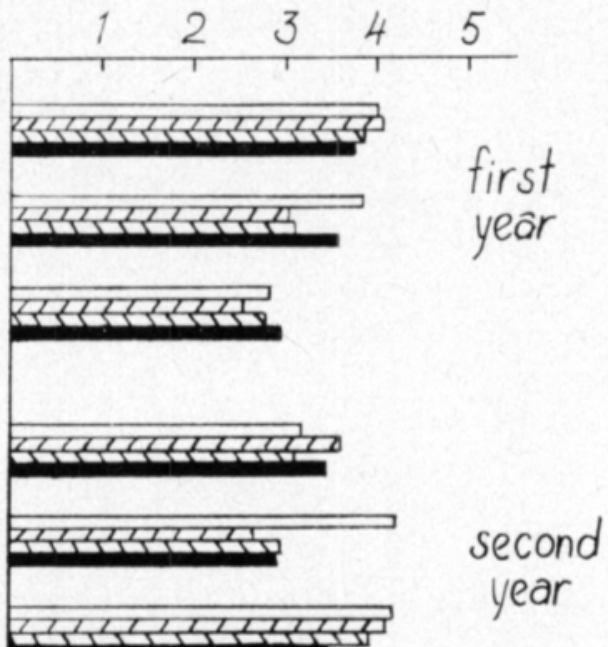

third

year

$\square$ Theoret. instr.

Pract. instr.

Neaching mater.

Examinations

Table 2. Correlations between the scores given by the same student on different aspects of the teaching.

Association between

$\mathbf{r}$

Theoretical \& practical instruction $\ldots \ldots \ldots \ldots \ldots \ldots \ldots \ldots \ldots \ldots \ldots . . . . \ldots \ldots$

Theoretical instruction \& examinations ......................... .73

Practical instruction $\&$ examinations .......................... .73

Practical instructions \& teaching material ....................... $\quad .80$

All correlations highly significant 
of 4.34 for the theoretical but only 3.49 for the practical teaching. The practical instruction in Special Pathology in the third year is also rated much lower than the theoretical teaching.

The fact that in these and some other subjects the practical instruction is rated very low together with the general tendency of the theoretical instruction receiving higher points should cause some concern in a field where special emphasis should be on practical matters.

The use and quality of the teaching material is rated at about the same level as the practical instruction, indicating that there is scope for improvement in many subjects. With a few exceptions examinations generally get lower scores than the theoretical instruction, but are usually rated higher than the practicals in those subjects where the latter get fairly low scores.

\section{Prediction of Overall Score}

Table 3 shows how closely associated with the overall score the scores for the individual subjects are. The highest correlations are noted for Biochemistry in the first year, Animal Production in the second, Medicine in the third and Reproduction \& Obstetrics in the final year. Correlations above 0.65 are also got for Microbiology, Special Pathology and Medicine (4th year).

Table 3. Total score prediction by using means of the individual subjects.

\begin{tabular}{|c|c|c|}
\hline Subject & $\begin{array}{l}\text { relation to } \\
\text { rall score } \\
\text { by student }\end{array}$ & \\
\hline \multicolumn{3}{|l|}{ 1st year: } \\
\hline Anatomy $\quad$, w..................................... & .46 & \\
\hline Physiology ........................................ & .35 & \\
\hline 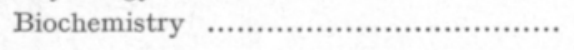 & .77 & \\
\hline \multicolumn{3}{|l|}{ 2nd year: } \\
\hline 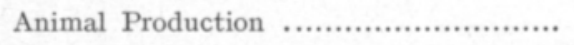 & .76 & \\
\hline Pharmacology .................................. & .63 & \\
\hline Microbiology ................................. & .69 & \\
\hline 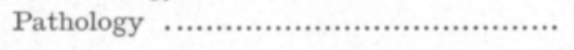 & .61 & \\
\hline \multicolumn{2}{|l|}{ 3rd year: } & \\
\hline 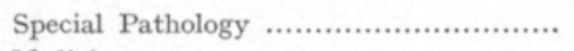 & .66 & \\
\hline 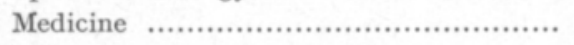 & .79 & \\
\hline Surgery & .61 & \\
\hline Reproduction \& Obstetrics ................... & .56 & \\
\hline \multicolumn{3}{|l|}{ 4th year } \\
\hline 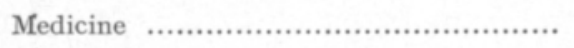 & .65 & \\
\hline 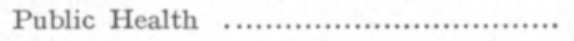 & .29 & \\
\hline Surgery & .42 & \\
\hline Reproduction \& Obstetrics ................... & .68 & \\
\hline
\end{tabular}

$\mathrm{r}>.304$ significant

$r>.393$ highly significant

$r>.490$ extremely significant 


\section{Comments by Graduates}

In addition to the scores given for the various subjects the graduates were also encouraged to give their comments on the teaching. These can be summarized as follows:

(1) The curriculum was generally felt to be too crowded; many graduates suggested extending the period of studies from 4 to $\mathbf{5}$ years.

(2) The practical aspects of the teaching were by many regarded as receiving too little emphasis; more tutorials, actual practical work and more films $\&$ slides were requested in almost all the replies.

(3) The variation between teachers was felt to be too large. Some teachers were considered totally incomprehensible. Generally the differences between African and foreign teachers were not found to be important, although the former often were outlined as more uncooperative and arrogant). Teachers should be taught more about how to teach, was a common wish.

(4) The examination system was criticised by a majority of the graduates. Generally it was felt that too much weight was given to nacademicn and theoretical aspects. Examinations should be more varied, spread out more in time (especially in the final year) and more attention should be paid to practical matters.

Of the individual subjects most dissatisfaction was expressed with Biochemistry (one teacher) and Embryology in the first year. In the second year Ecology \& Management, Virology and the practical teaching in Pharmacology were criticised. In the 3rd and 4th years Special Pathology, Reproduction, Obstetrics and some aspects of Medicine were criticised.

These comments indicate that there is fairly widespred dissatisfaction with the teaching in many subjects. Although some of the criticism may be exaggerated, the consistency of the remarks concerning these subjects shows (in accordance with e.g. KLAUSMEIER \& Ripple 1971) the need for a continuous assessment of teaching and teachers.

\section{REFERENCES}

CAmprell, J. R., 1972. In Touch With Students. A Philosophy for Teachers. Kelly Press Inc. Columbia, Missouri.

Klausmeier, H. J. \& Ripple, R. E., 1971. Learning and Human Abilities: Educational Psychology. 3rd Edit. Harper \& Row.

LindströM, U. B., 1975. Is Our Teaching Good Enough? Publ. by Assoc. of Facult. of Agric. in Africa; Printed by Int. Aeradio Ltd. Box 19012, Nairobi, Kenya, 13 pp. (Also available in French edition).

Thorndike, R. L. \& Hagen, Elisabeth, 1969. Measurement and Evaluation in Psychology and Education. Wiley Eastern Private.

Ms received October 21, 1977. 


\section{Arviointeja eläinlääketieteellisten aineiden opetuksesta Nairobin yliopistossa}

\section{U. B. LINDSTRÖM}

Kotieläinjalostuslaitos, Maatalouden tutkimuskeskus, Pl 18, 01301 Vantaa 30

V. 1975 Nairobin Yliopiston eläinlääketieteellisestä tiedekunnasta valmistuneille 62 opiskelijalle lähetetyistä kyselyistä saatiin vastaus 41:1tä. Opiskelijat arvioivat jokaisen aineen opetusta neljältä kannalta. Asteikkona käytettiin erittäin heikko $(=1)-$ erinomainen $(=5)$. Kaikkien opiskeluvuosien kokonaiskeskiarvoksi saatiin $3.51 \pm .45$, josta päättäen opetus arvosteltiin tyydyttäväksi mutta ei mitenkään erityisen hyväksi. Eri aineiden opetuksen välillä olivat vaihtelut suuret, heikoin tulos oli $2.78 \pm .78$ ja paras $3.94 \pm .68$ muuntelukertoimen vaihdellessa 14:stä 28:aan. Useiden aineiden osalta annettiin aineen käytännön opetukselle paljon huonommat pisteet kuin teoreettiselle opetukselle, yhdessä tapauksessa ero oli jopa 1.61 pistettä. Opetusmateriaalin ja kokeiden käyttökelpoisuus ja laatu arvioitiin yleensä heikommaksi kuin teoreettinen opetus. Oheiset tulokset samoin kuin vastauslomakkeisiin liitetyt huomautukset viittaavat siihen, että useiden aineiden opetuksessa olisi paljon parantamisen varaa. 
Appendix I. Questionnaire used in investigating teaching in Veterinary Medicine.

Evaluate the teaching you received at the University of Nairobi using the following scale: $1=$ very poor; $2=$ poor; $3=$ satisfactory; $4=$ good; $5=$ very good.

\section{Explanations;}

(a) Lectures and other theoretical instruction; (b) practicals, including farm visits, excursions etc.; (c) quality and use of teaching material; (d) relevant and meaningful examinations?

\section{First Year;}

Points

Anatomy and Histology

(a) theoretical instruction

(b) practical instruction

(c) teaching material

(d) examinations

Physiology

(a) theoretical instruction

(b) practical instruction

(c) teaching material

(d) examinations

Biochemistry
(a) theoretical instruction
(b) practical instruction
(c) teaching material
(d) examinations
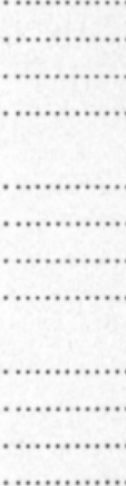

Was the teaching in any of the above subjects:

especially good?

especially poor?

\section{Secood Year;}

Points

Animal Production
(a) theoretical instruction
(b) practical instruction
etc. for all years \& subjects

\section{GENERAL COMMENTS}

What is your opinion of the teachers? Was there, for example, any difference between the African and the foreign teachers? Were the teachers generally well prepared, taking their job seriously? Were they willing to discuss various aspects of the teaching with the students?

Other comments about teaching \& curriculum: 
Appendix II. Comparisons of the different subjects within years by t-tests.

Comparisons

1st year:

Anatomy - Physiology

$$
\text { - Biochemistry }
$$

Physiology - ,

2nd year:

Anim.Prod. - Pharmac.

$$
\text { - Microbiol. }
$$$$
\text { - Pathology }
$$

Pharmacol. - Microbiol.

$$
\text { , - Pathology }
$$

Microbiol.

- $\quad 3$

3rd year:

Spec. Pathol.

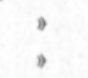

- Medicine

$$
\text { - Surgery }
$$

- Reprod. \& Obst.

Medicine - Surgery

$$
\text { - - Reprod. \& Obst. }
$$

Surgery

$$
\text { - }
$$

4th year:

Medicine - Public Health

- - Surgery

- - Reprod. \& Obst.

Public Health - Surgery

$$
\text { - Reprod. \& Obst. }
$$

Surgery
Difference betw. average scores t-value

$4.1 * * *$

1.13

$7.3 * * *$

0.61

$4.2 * * *$

$\begin{array}{ll}-0.04 & 0.2\end{array}$

$-0.57$

$-0.08$

0.3

$-0.53$

$3.3 * *$

$-0.04$

0.1

0.45

$3.3^{* *}$

$-0.46$

2.1*

$-0.90$

$-0.62$

$-0.44$

$2.5^{*}$

$-0.16$

0.28

1.6

* difference significant

** $\quad$ highly significant

*** extremely significant 